\title{
Correction to: Earth's gravity from space
}

\author{
Reiner Rummel ${ }^{1}$
}

Published online: 25 June 2021

(c) The Author(s) 2021

\section{Correction to: \\ Rendiconti Lincei. Scienze Fisiche e Naturali (2020) 31 (Suppl 1):S3-S13 \\ https://doi.org/10.1007/s12210-020-00889-8}

The article Earth's gravity from space, written by Reiner Rummel was originally published Online First without open access. After publication in volume 31, issue suppl 1, pages $\mathrm{S} 3-\mathrm{S} 13$, the Authors requested that the article be Open Choice to make the article an open access publication on June 9th.

This article is licensed under a Creative Commons Attribution 4.0 International License, which permits use, sharing, adaptation, distribution and reproduction in any medium or format, as long as you give appropriate credit to the original author(s) and the source, provide a link to the Creative Commons license, and indicate if changes were made. The images or other third-party material in this article are included in the article's Creative Commons license, unless indicated otherwise in a credit line to the material. If material is not included in the article's Creative Commons license and your intended use is not permitted by statutory regulation or exceeds the permitted use, you will need to obtain permission directly from the copyright holder. To view a copy of this license, visit https://creativecommons.org/licen ses/by/4.0/.

The original article has been corrected.

Open Access This article is licensed under a Creative Commons Attribution 4.0 International License, which permits use, sharing, adaptation, distribution and reproduction in any medium or format, as long as you give appropriate credit to the original author(s) and the source, provide a link to the Creative Commons licence, and indicate if changes were made. The images or other third party material in this article are included in the article's Creative Commons licence, unless indicated otherwise in a credit line to the material. If material is not included in the article's Creative Commons licence and your intended use is not permitted by statutory regulation or exceeds the permitted use, you will need to obtain permission directly from the copyright holder. To view a copy of this licence, visit http://creativecommons.org/licenses/by/4.0/.

Publisher's Note Springer Nature remains neutral with regard to jurisdictional claims in published maps and institutional affiliations.

The original article can be found online at https://doi.org/10.1007/ s12210-020-00889-8.

Reiner Rummel

reiner.rummel@tum.de

1 Astronomische und Physikalische Geodäsie, Technische

Universität München, Munich, Germany 